\title{
PENGARUH PENERAPAN STRATEGI PEMBELAJARAN THINK TALK WRITE (TTW) TERHADAP PRESTASI BELAJAR FISIKA PESERTA DIDIK KELAS VIII MTS
}

\author{
Irwandani \\ Program Studi Pendidikan Fisika, FTK IAIN Raden Intan Lampung; E-mail: dirwansurya@ yahoo.co.id
}

\begin{abstract}
Abstrak: Penelitian ini bertujuan untuk mengetahui dan mendeskripsikan seberapa besar pengaruh strategi pembelajaran TTW pada peserta didik kelas VIII MTs Al-Hikmah Bandar Lampung. Metode penelitian menggunakan kuasi eksperimen dengan desain Control Group Pretest-Posttest. Sampel penelitian terbagi dalam dua kelas, yaitu kelas eksperimen dan kelas kontrol. Kelas eksperimen menggunakan pembelajaran dengan strategi TTW sementara kelas kontrol menggunakan strategi pembelajaran konvensional. Berdasarkan hasil penelitian diperoleh hasil bahwa kelas eksperimen diperoleh $\mathrm{N}$-gain sebesar 0,609 sementara untuk kelas kontrol diperoleh $\mathrm{N}$-gain sebesar 0,561.
\end{abstract}

Kata kunci: prestasi belajar, strategi belajar, think talk write. 


\section{PENDAHULUAN}

Pendidikan yang berkualitas merupakan cerminan dari kemajuan suatu bangsa, karena pendidikan merupakan salah satu komponen bangsa yang sangat penting untuk menentukan kualitas, kecerdasan dan kemajuan bangsa itu sendiri. Pendidikan memiliki peranan penting dalam kehidupan yaitu sebagai media strategis untuk meningkatkan sumber daya manusia suatu negara.

Undang-Undang No.20 Tahun 2003 menyatakan bahwa tujuan pendidikan nasional adalah mengembangkan potensi peserta didik agar menjadi manusia yang beriman kepada Tuhan Yang Maha Esa, berakhlak mulia, sehat, berilmu, cakap, kreatif, mandiri, dan menjadi warga negara yang demokratis serta bertanggung jawab (Trianto, 2010). Dalam hal ini semua satuan pendidikan tentunya hendak mencapai tujuan pendidikan nasional.

Untuk mencapai hal tersebut, maka diperlukan upaya yang sistematis dan berkesinambungan. Salah satunya adalah dengan berupaya untuk terus memperbaiki kualitas pembelajaran. Belajar dan pembelajaran merupakan suatu proses yang dilakukan seseorang untuk memperoleh suatu perubahan secara menyeluruh sebagai hasil dari interaksi dengan lingkungan dan pengalamannya sendiri serta bersifat terus menerus. Proses belajar yang ideal adalah adanya interaksi antara guru dengan peserta didik yang terjadi di dalam kelas, serta penerapan model, strategi, metode dan media pembelajaran yang tepat dan mendukung.

Strategi pembelajaran adalah cara yang akan digunakan oleh pengajar untuk memilih kegiatan belajar yang akan digunakan selama proses pembelajaran (Uno, 2012). Dalam proses belajar penggunaan strategi pembelajaran yang tepat sangat diperlukan, karena strategi pembelajaran memiliki peran penting yaitu untuk menciptakan suasana belajar yang efektif, menyenangkan dan mengaktifkan kemampuan yang dimiliki peserta didik. Sehingga jika guru mampu memilih dan menggunakan strategi pembelajaran yang sesuai dengan kondisi, situasi dan kebutuhan peserta didik maka prestasi belajar peserta didik juga akan mengalami peningkatan.

Namun, berdasarkan hasil observasi yang dilakukan peneliti di salah satu MTs di Bandar Lampung diketahui bahwa dari empat kelas yang dijadikan data ternyata sekitar $70 \%$ peserta didik mendapat nilai di bawah Kriteria Ketuntasan Mengajar (KKM) yang telah ditetapkan.

Berdasarkan data tersebut, peneliti menduga terdapat masalah pada saat proses belajar mengajar. Dugaan tersebut diperkuat dengan adanya hasil wawancara dengan guru IPA yang mengajar di MTs tersebut. Berdasarkan hasil wawancara diketahui bahwa dalam proses mengajar guru belum menggunakan strategi pembelajaran yang bervariasi. Hal ini ditunjukkan dengan pembelajaran yang diterapkan masih cenderung teacher centered atau berpusat pada guru dengan penerapan metode ceramah dan diskusi yang kurang terarah.

Oleh karena itu, diperlukan strategi pembelajaran yang senantiasa digunakan dan dikembangkan oleh guru untuk mengkonstruksi pembelajaran IPA dengan baik dan benar. Strategi pembelajaran yang baik adalah strategi yang dapat mengembangkan aktivitas, interaksi, komunikasi, menalar, serta melibatkan peserta didik secara keseluruhan. Strategi pembelajaran yang memungkinkan peserta didik untuk berinteraksi satu sama lain diantaranya adalah strategi pembelajaran Think Talk Write (TTW).

Strategi pembelajaran Think Talk Write (TTW) adalah sebuah pembelajaran yang dimulai dengan berfikir melalui bahan bacaan (menyimak, mengkritis, dan alternatif solusi), hasil bacaannya dikomunikasikan dengan presentasi, diskusi, dan kemudian membuat laporan 
hasil presentasi (Hamdayana, 2014). Dalam kegiatan ini proses berfikir dapat dilihat dari proses membaca suatu teks kemudian membuat catatan tentang apa yang telah dibaca lalu ditulis dengan menggunakan bahasa sendiri. Melalui strategi pembelajaran TTW peserta didik juga diajarkan untuk berfikir dengan tahap awalnya membaca bahan bacaan yang disediakan kemudian berpikir dan yang terakhir adalah menulis.

Beberapa penelitian terdahulu terkait dengan penelitian TTW adalah penelitian yang dilakukan oleh Inayah (2008) pada kelas matematika mengemukakan bahwa rata-rata hasil belajar matematika peserta didik MTs yang menggunakan strategi ini lebih tinggi dari pada rata-rata hasil belajar matematika yang menggunakan pembelajaran konvensional. Akan tetapi temuan itu dibantah oleh penelitian Maesaroh (2010), yang mengemukakan bahwa tidak terdapat pengaruh yang signifikan dari penerapan strategi pembelajaran TTW terhadap hasil belajar fisika peserta didik SMA.

Berdasarkan hasil review dari penelitian-penelitian terdahulu tersebut, maka peneliti berupaya untuk melakukan penelitian lanjutan dengan tujuan untuk mengetahui sejauh mana strategi pembelajaran TTW mampu memberikan pengaruh yang signifikan terhadap prestasi belajar IPA fisika untuk peserta didik MTs.

\section{KAJIAN PUSTAKA}

\section{Pembelajaran Kooperatif}

Model pembelajaran merupakan landasan atau acuan yang digunakan dalam praktik pembelajaran dan merupakan hasil dari buah pemikiran serta penurunan teori psikologi pendidikan dan teori belajar yang dirancang dan disusun berdasarkan kurikulum yang disesuaikan dengan perkembangan dunia pendidikan.

Salvin dalam Solihatin (2008) mengatakan bahwa cooperative learning adalah suatu model pembelajaran dimana siswa belajar dan bekerja dalam kelompokkelompok kecil secara kolaboratif yang anggota kelompoknya teridi dari 4-6 orang dengan struktur kelompok yang bersifat heterogen. Sedangkan menurut Kunandar (2011) model pembelajaran kooperatif adalah pembelajaran yang secara sadar dan sengaja mengembangkan interaksi yang saling asuh antar siswa untuk menghindari ketersinggungan dan kesalah pahaman yang dapat menimbulkan permusuhan.

Selanjutnya Lie (2008) menyebutkan bahwa pelaksanaan prosedur model cooperative learning dengan benar akan memungkinkan pendidik mengelola kelas dengan lebih efektif.

Berdasarkan pengertian di atas dapat disimpulkan bahwa model pembelajaran kooperatif merupakan model pembelajaran yang secara aktif melibatkan peserta didik dalam kegiatan kelompok untuk memecahkan suatu permasalahan dan mencapai tujuan pembelajaran.

Tujuan pembelajaran koopertaif adalah agar peserta didik dapat belajar secara berkelompok, saling menghargai pendapat dan memberikan kesempatan kepada orang lain utuk mengemukakan gagasannya (Isjoni, 2013). Adapun dalam penerapannya menurut Ibrahim dalam Hamdayana (2014) menyebutkan bahwa manfaat dari pembelajaran kooperatif yaitu:

1) Meningkatkan pencurahan waktu pada tugas.

2) Rasa harga diri menjadi lebih tinggi.

3) Angka putus sekolah menjadi lebih rendah.

4) Penerimaan terhadap perbedaan individu menjadi lebih besar.

5) Memperbaiki kehadiran.

6) Perilaku mengganggu menjadi lebih kecil.

7) Konflik anatar pribadi berkurang.

8) Sikap apatis berkurang.

9) Pemahaman yang lebih mendalam.

10) Motivasi belajar lebih besar.

11) Hasil belajar lebih tinggi. 
12) Meningkatkan kebaikan budi pekerti, kepekaan, dan toleransi.

Sementara itu, menurut Rima dkk (2013) mengatakan bahwa manfaat dari cooperatif learning antara lain dapat meningkatkan aktifitas belajar siswa dan prestasi akademik, membantu siswa dalam mengembangkan keterampilan berkomunikasi secara lisan, keterampilan sosial siswa, meningkatkan rasa percaya diri siswa, meningkatkan hubungan positif antar siswa.

\section{Strategi Pembelajaran Think Talk Write (TTW)}

Strategi Think talk write (TTW) merupakan strategi pembelajaran untuk melatih keterampilan peserta didik dalam menulis (Shoimin, 2013). Secara etimologi, think diartikan dengan "berpikir", talk diartikan dengan "berbicara", sedangkan write diartikan sebagai "menulis". Strategi pembelajaran ini diperkenalkan oleh Huinker \& Laughlin tahun 1996 (Hamdayama, 2014), yang menyebutkan bahwa strategi pembelajaran ini pada dasarnya dibangun melalui berfikir, berbicara, dan menulis.

Menurut Huda (2014) Think Talk Write (TTW) adalah strategi yang memfasilitasi latihan berbahasa secara lisan dan menulis bahasa tersebut dengan lancar, dan memiliki sintak yakni think (berfikir), talk (berbicara/ berdiskusi), dan write (menulis). Strategi pembelajaran TTW adalah strategi pembelajaran yang dimulai dari alur berfikir melalui bahan bacaan (menyimak, mengkritisi dan alternatif solusi), selanjutnya berbicara dengan melakukan diskusi, presentasi dan terakhir menulis dengan membuat laporan hasil diskusi maupun presentasi (Suyanto, 2009).

Berdasarkan penjelasan di atas yang dimaksud dengan strategi pembelajaran TTW adalah strategi pembelajaran yang mengabungkan berbagai kemampuan seperti (berpikir, berbicara, dan menulis) kedalam satu kegiatan untuk mencapai satu tujuan. Tujuan yang dimaksud dalam hal ini adalah prestasi belajar peserta didik.

Aktivitas think (berfikir) peserta didik melakukan diskusi dengan dirinya sendiri melalui bahan bacaan baik itu berupa LKS, lembar diskusi dan lain-lain yang berisi tentang pemecahan terhadap suatu masalah yang diberikan, kemudian mencatat hal-hal yang berkaitan dengan penyelesaian masalah baik berupa langkah-langkah, buah pemikiran atau yang lainnya dalam bentuk catatan kecil dengan menggunakan bahasanya sendiri.

Pada tahap selanjutnya yaitu talk (berbicara), dalam tahap ini peserta didik diminta untuk melakukan kegiatan berupa berkomunikasi dan berinteraksi menggunakan bahasa yang dapat dipahami oleh anggota kelompoknya untuk membahas tentang penyelesaian dari masalah yang diberikan. Pada proses ini secara tidak langsung peserta didik dilatih kemampuan berbicaranya melalui mengungkapkan dan merefleksikan pemikirannya kepada anggota kelompoknya.

Dalam proses ini guru berfungsi sebagai fasilitator serta memantau jalannya proses komunikasi antar peserta didik dan mengarahkan kelompok dalam memahami materi jika terjadi kesulitan. Guru juga berperan penting sebagai motivator, dalam hal ini guru harus meberikan dorongan atau motivasi kepada seluruh peserta didik agar mereka mempunyai keberanian untuk menyampaikan pemikrannya dan menjadikan kegiatan diskusi dapat berjalan dengan aktif.

Tahap yang ketiga yaitu write (menulis), pada tahap ini peserta didik menuliskan hasil pemikiran yang telah dikolaborasikan dengan diskusi kelompok dan ditulis pada LKS yang disediakan. Aktivitas menulis ini membantu peserta didik dalam menganalisa pemikirannya dan teman diskusinya kemudian menghubungkan dan dituangkan dalam bentuk tulisan. Dalam aktivitas menulis ini 
dapat juga diamanfaatkan oleh guru untuk memantau sejauh mana pemahaman konsep yang diterima oleh peserta didik serta memantau kesalahan peserta didik, miskonsepsi, dan konsepsi peserta didik. Menurut Maritis Yamin dalam Jumanta, aktivitas selama siswa dalam tahap write ini adalah (1) menulis solusi terhadap masalah, (2) mengorganisasikan semua pekerjaan langkah demi langkah, (3) mengoreksi semua pekerjaan, (4) meyakini bahwa pekerjaannya yang terbaik (Hamdayana, 2014)

Tahap terakhir dari strategi pembelajaran ini adalah presentasi. Tujuan dari presentasi ini adalah untuk berbagi informasi dari masing-masing kelompok, sehingga guru tidak perlu mengulang materi secara keseluruhan. Dalam kegiatan ini presentasi disampaikan oleh salah seorang perwakilan kelompok untuk menyampaikan hasil diskusi dengan kelompoknya dan ditanggapi oleh kelompok lain. Setelah itu baru peserta didik diminta untuk menyimpulkan materi yang disampaikan secara bersama-sama.

\section{Langkah-Langkah Pembelajaran Think Talk Write (TTW)}

Menurut Mahftuh dan Nurmani dalam Hamdayana (2014) disebutkan bahwa langkah-langkah untuk melaksanakan TTW adalah sebagai berikut:

Tabel 1. Langkah Strategi Pembelajaran Think Talk Write (TTW)

\begin{tabular}{|c|c|c|}
\hline No & Kegiatan guru & Aktivitas siswa \\
\hline 1 & Guru menjelaskan tentang Think Talk Write. & Siswa memperhatikan penjelasan guru. \\
\hline 2 & Guru menyampaikan tujuan pembelajaran. & Memahami tujuan pembelajaran. \\
\hline 3 & $\begin{array}{l}\text { Guru menjelaskan sekilas tentang materi yang } \\
\text { akan didiskusikan. }\end{array}$ & $\begin{array}{l}\text { Siswa memperhatikan dan berusaha } \\
\text { memahami materi. }\end{array}$ \\
\hline 4 & $\begin{array}{l}\text { Guru membentuk siswa dalam kelompok, setiap } \\
\text { kelompok terdiri atas 3-5 orang siswa (yang } \\
\text { dikelompokkan secara heterogen) }\end{array}$ & Siswa mendengarkan kelompoknya. \\
\hline 5 & $\begin{array}{l}\text { Guru membagikan LKS kepada setiap siswa. } \\
\text { Siswa membaca soal LKS, memahami masalah } \\
\text { secara individual, dan dibuatkan catatan kecil } \\
\text { (think). }\end{array}$ & $\begin{array}{l}\text { Menerima dan mencoba memahami LKS } \\
\text { kemudian membuat catatan kecil untuk } \\
\text { diskusi dengan teman kelompoknya. }\end{array}$ \\
\hline 6 & $\begin{array}{l}\text { Mempersiapkan siswa untuk berinteraksi dengan } \\
\text { teman kelompok untuk membahas isi LKS (talk). } \\
\text { Guru sebagai mediator lingkungan belajar. }\end{array}$ & $\begin{array}{l}\text { Siswa berdiskusi untuk merumuskan } \\
\text { kesimpulan sebagai hasil dari diskusi } \\
\text { dengan anggota kelompoknya. }\end{array}$ \\
\hline 7 & $\begin{array}{l}\text { Mempersiapkan siswa menulis sendiri } \\
\text { pengetauhan yang diperolehnya sebagai hasil } \\
\text { kesepakatan dengan anggota kelompoknya } \\
\text { (write). }\end{array}$ & $\begin{array}{l}\text { Menulis secara sistematis hasil diskusinya } \\
\text { untuk dipresentasikan. }\end{array}$ \\
\hline 8 & $\begin{array}{l}\text { Guru meminta masing-masing } \text { kelompok } \\
\text { mempresentasikan pekerjaannya }\end{array}$ & Siswa mempresentasikan hasil diskusinya. \\
\hline 9 & $\begin{array}{l}\text { Guru meminta siswa dari kelompok lain untuk } \\
\text { menanggapi jawaban dari kelompok lain. }\end{array}$ & Siswa menangapi jawaban temannya. \\
\hline
\end{tabular}

Beberapa komponen penting yang dapat mempelancar dan berperan penting dalam proses belajar dengan menggunakan strategi pembelajaran TTW adalah sebagai berikut:

1) Guru yang berkompeten dan profesional.

2) Anak didik yang aktif dalam proses pembelajaran.
3) Buku bacaan yang sesuai dengan topik materi yang diajarkan dengan jumlah yang banyak dan bervariasi.

4) Beberapa teknik pembelajaran yang mempunyai peranan cukup penting dalam terlaksananya strategi Think Talk Write dalam pembelajaran, agar dapat tercapai tujuan yang telah ditentukan. 
Teknik Penyampaian strategi Pembelajaran TTW bukan hanya menekankan pada pelaksanaan, dan aplikasinya. Tetapi juga menyinggung teknik lain yang dapat digunakan dalam pengajaran ini seperti ceramah, diskusi, resistasi, tanya jawab dan lain-lain. Selanjutnya, dalam strategi pembelajaran TTW aspek yang ditunjukaan adalah berupa berpikir kreatif, berkomunikasi, interaksi, menulis dan lain-lain.

Menurut Hamdayana (2014), teknikteknik yang bisa digunakan sebagai pengantar pelaksanaan strategi TTW dalam pembelajaran adalah diskusi, ceramah, resistasi (pemberian tugas), tanya jawab, dan penemuan.

Dalam pelaksanaanya penggunaan teknik-teknik ini dapat disesuaikan dengan alokasi waktu yang ditentukan oleh pihak sekolah terhadap mata pelajaran yang akan diajarkan dan situasi serta kondisi peserta didik.

\section{Manfaat Strategi Pembelajaran Think Talk Write (TTW)}

Dalam Hamdayana (2014), disebutkan bahwa manfaat dari strategi pembelajaran kooperatif tipe TTW adalah sebagai berikut:

1) Model pembelajaran berbasis komunikasi dengan stretegi Think Talk Write dapat membantu siswa dalam mengkonstruksi pengetahuannya sendiri sehingga pemahaman konsep siswa menjadi lebih baik, siswa dapat mengkomunikasikan atau mendiskusikan pemikirannya dengan temannya sehingga siswa saling membantu dan saling bertukar pikiran. Hal ini dapat membantu siswa dalam memahami materi yang diajarkan.

2) Model pembelajaran berbasis komunikasi dengan strategi Think Talk Write dapat melatih siswa untuk menuliskan hasil diskusinya kebentuk tulisan secara sistematis sehingga siswa akan lebih memahami materi dan membantu siswa untuk mengkomunikasikan ide-idenya dalam bentuk tulisan.

\section{Kelebihan Dan Kelemahan strategi Pembelajaran Think Talk Write (TTW)}

Kelebihan strategi pembelajaran Think Talk Write (TTW) adalah sebagai berikut:

1) Mempertajam seluruh keterampilan berpikir visual.

2) Mengembangkan permecahan yang bermakna dalam rangka memahami materi ajar.

3) Dengan memberikan soal open minded, dapat mengembangkan terampilan berpikir kritis dan kreatif siswa.

4) Dengan berinteraksi dan berdiskusi dengan kelompok akan melibatkan siswa secara aktif dalam belajar.

5) Membiasakan siswa berfikir dan berkomunikasi dengan teman, guru, dan bahkan dengan diri mereka sendiri.

Adapun yang menjadi kelemahan strategi pembelajaran Think Talk Write (TTW) adalah sebagai berikut:

1) Ketika siswa bekerja dalam kelompok itu mudah kehilangan kemampuan dan kepercayaan, karena didominasi oleh siswa yang mampu.

2) Guru harus benar-benar menyiapkan semua media dengan matang agar dalam menerapkan strategi Think Talk Write tidak mengalami kesulitan.

\section{METODE PENELITIAN}

Metode penelitian ini menggunakan metode kuasi eksperimen atau eksperimen semu. Dengan desain Control Group Pretest-Postest yang digambarkan dalam tabel berikut: (Arikunto, 2013) 
Tabel 2. Desain Penelitian

\begin{tabular}{|c|c|c|c|}
\hline Kelas & Pretest & Perlakuan & Postest \\
\hline $\mathrm{E}$ & $\mathrm{T}_{1}$ & $\mathrm{X}$ & $\mathrm{T}_{2}$ \\
\hline $\mathrm{K}$ & $\mathrm{T}_{1}$ & $\mathrm{Y}$ & $\mathrm{T}_{2}$ \\
\hline
\end{tabular}

Ket.:

$\mathrm{E}=$ Kelas eksperimen

$\mathrm{K}=$ Kelas kontrol

$\mathrm{X}=$ Pembelajaran dengan strategi TTW

$\mathrm{Y}=$ Pembelajaran strategi konvensional

$\mathrm{T}_{1}=$ Soal pretest (sebelum perlakuan)

$\mathrm{T}_{2}=$ Soal postest (setelah perlakuan)

Populasi dalam penelitian ini adalah seluruh peserta didik kelas VIII MTs AlHikmah Bandar Lampung Tahun ajaran $2014 / 2015$. Adapun sampel yang digunakan dipilih dengan teknik purposive sampling sehingga diperoleh dua kelompok untuk kelas eksperimen dan kelas kontrol.

Prosedur dari penelitian ini mengacu pada empat tahapan utama, meliputi studi pendahuluan, persiapan, pelaksanaan dan analisis hasil dan penyusunan laporan. Kegiatan studi pendahuluan dilakukan untuk memperoleh gambaran aktual tentang permasalahan pembelajaran fisika di kelas. Setelah diperoleh permasalahan melalui kegiatan observasi, kemudian dilakukan analisis terhadap masalah tersebut. Langkah selanjutnya adalah melakukan studi literatur untuk mencari dan menyusun langkah penyelesaian masalah tersebut.

Setelah studi pendahuluan dilakukan, peneliti kemudian melakukan tahap persiapan. Kegiatan utama yang dilakukan dalam tahapan ini adalah menyusun perangkat pembelajaran, instrumen penelitian, dan melakukan ujicoba. Penyusunan perangkat pembelajaran terdiri dari rencana pelaksanaan pembelajaran (RPP), lembar kerja siswa, dan soal untuk kegiatan diskusi dan segala perlengkapannya. Selanjutnya peneliti membuat instrumen penelitian yang terdiri atas soal-soal kognitif berbentuk pilihan ganda yang disusun berdasarkan indikator- indikator yang disesuaikan dengan kurikulum.

Setelah disusun, instrumen penelitian kemudian dikonsultasikan dan diberi penilaian atau judgement oleh dosen ahli. Selanjutnya, instumen diujicobakan terlebih dahulu untuk melihat kualitas dan kelayakannya. Adapun instrumen yang layak untuk dijadikan instrumen penelitian berjumlah 26 istrumen dari total 33 instrumen yang diujicobakan.

Tahap selanjutnya adalah pelaksanaan. Setelah semua perangkat dan instrumen telah siap, maka dilakukan pelaksanaan penelitian. Kegiatan penelitian dilakukan di kelas eksperimen dan kontrol. Dalam tahap ini dilakukan juga kegiatan pengumpulan data dengan teknik pengumpulan berupa observasi, dokumentasi, wawancara dan tes prestasi belajar (tes kognitif).

Selanjutnya, tahap terakhir adalah tahap analisis dan penyusunan laporan. Dalam tahap analisis ini dilakukan berbagai teknik analisis data dengan menghitung gain yang dinormalisasi ( $\mathrm{N}$-gain) dari nilai tes awal (pretest) dan tes akhir (postest) terhadap prestasi belajar peserta didik baik yang kelas eksperimen maupun kelas kontrol. Selain itu, dilakukan pula analisis terhadap hasil-hasil observasi, wawancara dan dokumentasi yang dilakukan selama kegiatan penelitian. Data-data tersebut kemudian diuji secara statistik dan ditelaah untuk kemudian dianalisis. Hasil analisis digunakan untuk menguji hipotesis yang diajukan dalam penelitian. Hasil penelitian kemudian disusun sedemikian rupa sesuai dengan kaidah penyusunan karya ilmiah.

\section{HASIL PENELITIAN}

Hasil utama yang diperoleh dari penelitian ini adalah prestasi belajar peserta didik setelah diterapkan strategi pembelajaran Think Talk Write (TTW). Berikut disajikan hasil pretest dan postest dari kelas eksperimen: 


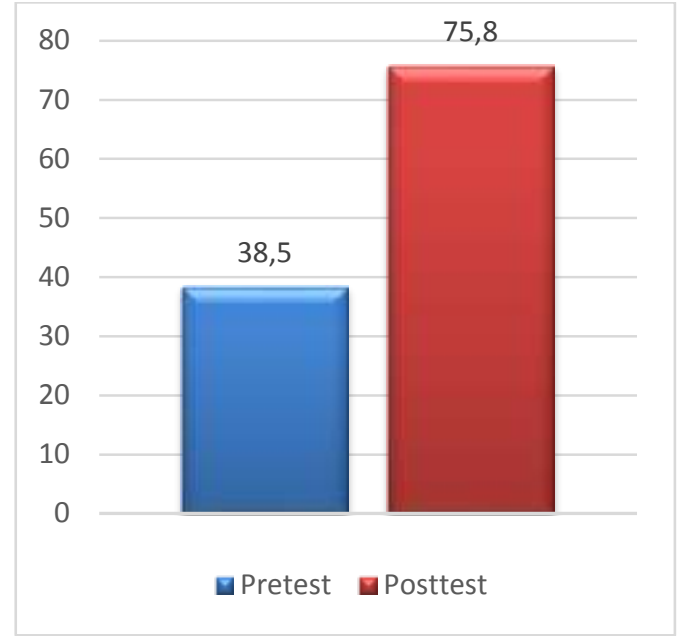

Gambar 1 Grafik Hasil Rata-rata Pretest dan Posttest Kelas Eksperimen.

Dari grafik di atas diketahui bahwa hasil rata-rata pretest yang diperoleh oleh kelas eksperimen adalah sebesar 38,5 dan hasil rata-rata posttest yang diperoleh oleh kelas eksperimen adalah sebesar 78,5. Dengan rata-rata $\mathrm{N}$-gain yang diperoleh adalah sebesar 0,609.

Adapun untuk kelas kontrol diperoleh hasil yang disajikan dalam grafik sebagai berikut:

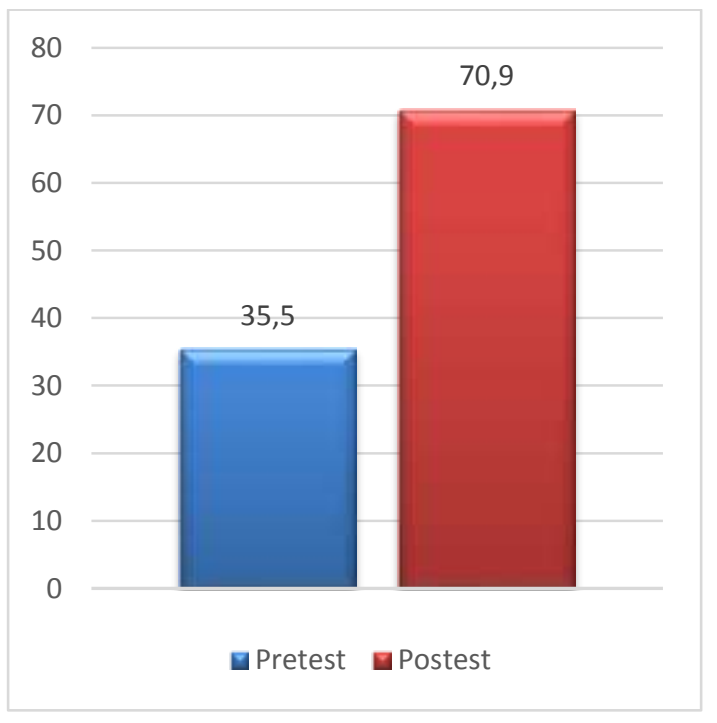

Gambar 2 Grafik Hasil Rata-rata Pretest dan Posttest Kelas Kontrol.

Dari grafik di atas diketauhi bahwa hasil rata-rata pretes yang diperoleh oleh kelas kontrol adalah sebesar 35,5 dan hasil rata-rata posttes yang diperoleh oleh kelas kontrol adalah sebesar 70,9. Dengan ratarata $\mathrm{N}$-gain yang diperoleh sebesar 0,561.

Adapun berbandingan $\mathrm{N}$-gain antara kelas eksperimen dan kontrol adalah sebagai berikut.

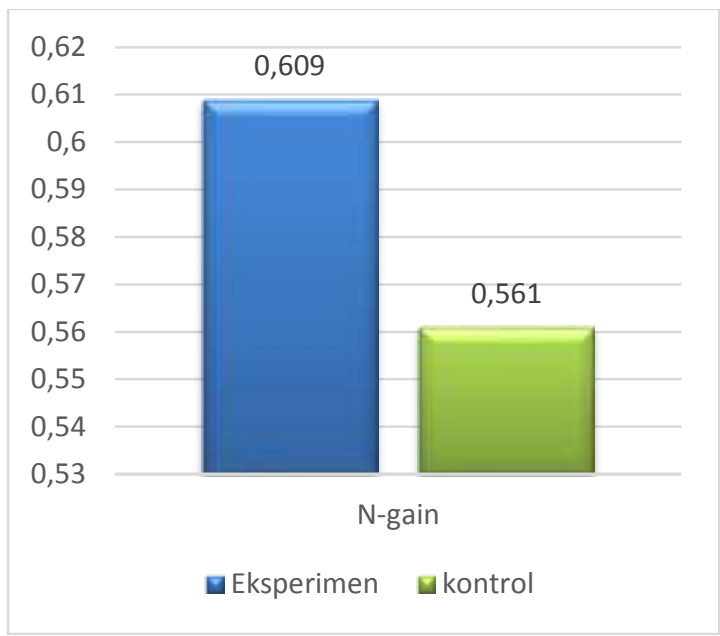

Gambar 3 Grafik Rata-rata Perbandingan Ngain Kelas Eksperimen dan Kelas Kontrol.

Dari grafik di atas, diketahui bahwa rata-rata $N$-gain prestasi belajar peserta didik yang menggunakan strategi pembelajaran think talk write (TTW) sebesar 0,609, sedangkan rata-rata $N$-gain prestasi belajar peserta didik dengan pembelajaran konvensional sebesar 0,561.

Dalam penelitian ini, ada tiga jenjang ranah kognitif yang diamati, yaitu $C_{1}$ (pengetahuan), $\mathrm{C}_{2}$ (Pemahaman), dan $\mathrm{C}_{3}$ (Penerapan). Berdasarkan hasil perhitungan, diketahui bahwa rata-rata prestasi belajar peserta didik pada ranah kognitif pengetahuan $\left(\mathrm{C}_{1}\right)$ di kelas eksperimen sebesar 30,71, pada ranah kognitif pemahaman $\left(\mathrm{C}_{2}\right)$ sebesar 30,80, dan pada ranah kognitif penerapan $\left(\mathrm{C}_{3}\right)$ sebesar 30,87.

Adapun rata-rata prestasi belajar peserta didik pada ranah kognitif pengetahuan $\left(\mathrm{C}_{1}\right)$ di kelas kontrol sebesar 28,85 , pada ranah kognitif pemahaman $\left(\mathrm{C}_{2}\right)$ sebesar 29,90, dan pada ranah kognitif penerapan $\left(\mathrm{C}_{3}\right)$ sebesar 28,25. Untuk lebih jelasnya disajikan dalam grafik perbandingan berikut. 


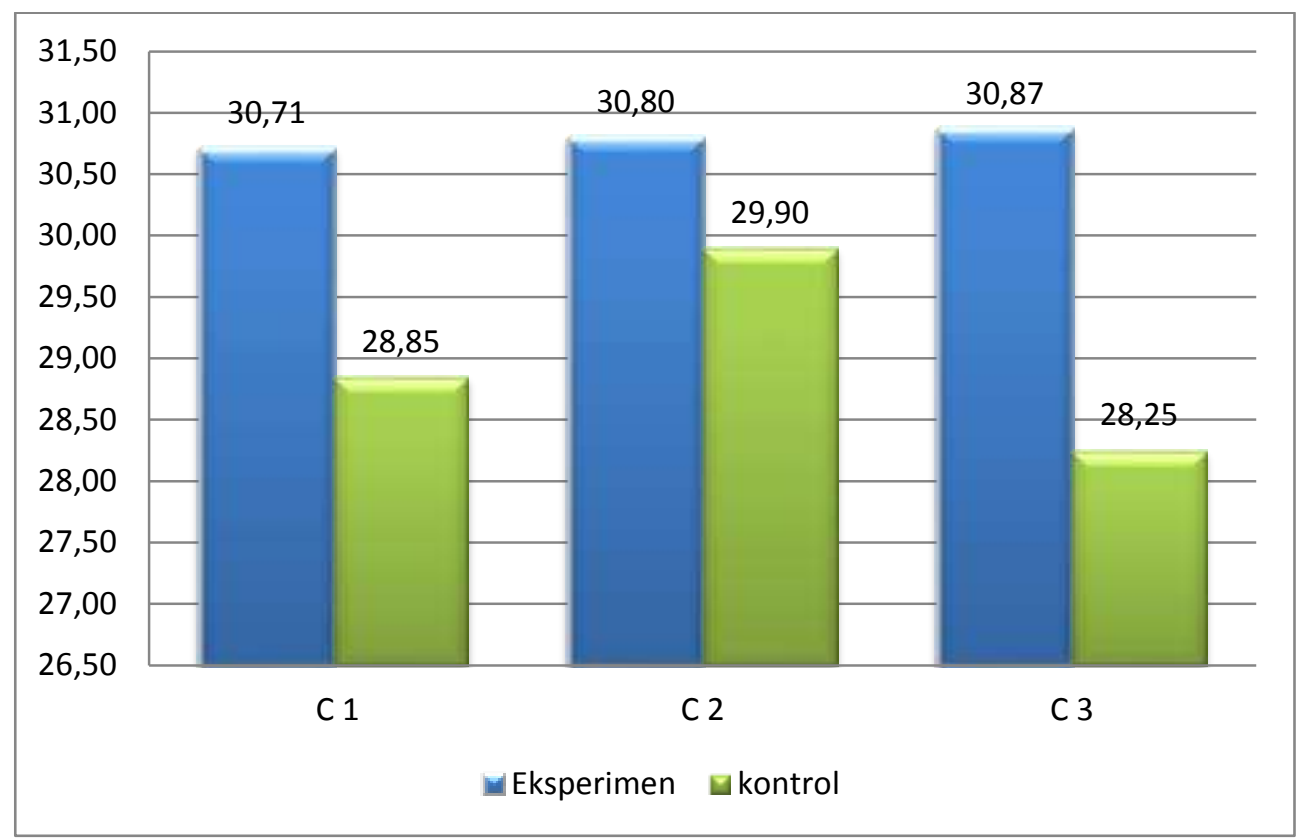

Gambar 4 Grafik Perbandingan Rata-rata Pretasi Belajar Setiap Jenjang Kognitif.

Dari grafik rata-rata pretest dan posttest yang diperoleh kelas eksperimen menunjukkan bahwa adanya peningkatan sebesar $50,7 \%$ dari rata-rata pretest yang diperoleh peserta didik sebelum diberi perlakuan. Peningkatan ini diindikasikan pada penerapan strategi pembelajaran think talk write (TTW), dimana peserta didik diminta untuk terlibat langsung dalam mempelajari dan memahami suatu materi secara berkelompok dengan tahapantahapan berfikir melalui bahan bacaan, berkomunikasi dalam diskusi kelompok, dan membuat ringkasan dari hasil diskusi dengan bahasa sendiri. Kemudian berdasarkan hasil wawancara penerapan strategi pembelajaran TTW mendapat respons yang baik dari peserta didik yaitu sebesar $65 \%$ peserta didik menyatakan tertarik dan mampu memahami materi yang dipelajari dengan mudah.

Sedangkan, dari grafik rata-rata pretest dan posttest yang diperoleh kelas kontrol menunjukkan bahwa adanya peningkatan sebesar $50 \%$ dari rata-rata pretest yang diperoleh peserta didik sebelum diberi perlakuan. Peningkatan ini diindikasikan pada penggunaan pembelajaran konvensional, serta faktor lain di luar penelitian.

Berdasarkan hasil perhitungan $\mathrm{N}$ Gain, diketahui bahwa prestasi belajar peserta didik yang menggunakan strategi pembelajaran TTW rata-rata $\mathrm{N}$-gainnya sebesar 0,609. Sedangkan pada kelas yang menggunakan strategi pembelajaran konvensional $\mathrm{N}$-gain yang diperoleh sebesar 0,561. Dari informasi tersebut dapat diketahui bahwa prestasi belajar peserta didik yang menggunakan strategi pembelajaran TTW lebih baik dari pembelajaran dengan strategi konvensional.

Perbedaan yang terjadi dikarenakan dalam pelaksanaannya strategi TTW lebih menekankan tanggung jawab peserta didik secara individu dan kelompok yang harus sama-sama memahami materi serta menyelesaikan tugas secara bersama-sama. Sebagaimana dijelaskan dalam landasan teori, bahwa strategi pembelajaran TTW ini merupakan cabang dari model pembelajaran cooperative yang dapat 
merangsang serta melibatkan siswa secara aktif dalam kegiatan belajar mengajar seperti berdiskusi, kerjasama, serta saling membantu anggota kelompoknya dalam belajar. Kemudian, dalam pelaksanaannya strategi pembelajaran TTW terlaksana 100 $\%$.

Meskipun demikian, masih ada juga peserta didik yang masih enggan terlibat aktif dengan strategi TTW. Hal ini dikarenakan mereka belum terbiasa dengan strategi ini. Hal inilah yang menyebabkan perbedaan prestasi belajar yang dicapai oleh kelas eksperimen dan kelas kontrol masih tidak terlalu signifikan.

Selanjutnya, untuk rata-rata prestasi belajar peserta didik terhadap ranah kognitif diperoleh bahwa pada semua ranah baik ranah $\mathrm{C}_{1}, \mathrm{C}_{2}$, dan $\mathrm{C}_{3}$ kelas eksperimen mengungguli kelas kontrol. Hal ini dimungkinkan karena strategi pembelajaran think talk write lebih menekankan pada aspek pengetahuan dengan tahapan think (berfikir), talk (berbicara), write (menulis) secara mandiri, sehingga setiap peserta didik memiliki pengetahuan terhadap materi yang diajarkan.

Hasil penelitian ini membuktikan bahwa penggunaan strategi pembelajaran yang bervariasi dan disesuaikan dengan materi yang akan diajarkan dapat memberikan prestasi belajar yang lebih baik pada peserta didik. Sejalan dengan penelitian yang relevan, penelitian ini juga sesuai dengan landasan teori, serta kerangka berfikir yaitu strategi pembelajaran think talk write dapat memberikan alternatif baru dalam pembelajaran, khususnya pembelajaran IPA Fisika.

\section{SIMPULAN DAN SARAN Simpulan}

Berdasarkan hasil dan pembahasan, maka dapat disimpulkan sebagai berikut:

1. Terdapat pengaruh dari pembelajaran dengan strategi think talk write (TTW) terhadap prestasi belajar peserta didik kelas VIII MTs.

2. Hasil perhitungan N-gain diperoleh sebesar 0,609 untuk kelas yang menggunakan strategi pembelajaran think talk write (TTW). Sementara untuk kelas yang menggunakan strategi konvensional diperoleh $\mathrm{N}$-gain sebesar 0,561. Hal ini membuktikan bahwa Strategi pembelajaran think talk write (TTW) lebih baik dalam meningkatkan prestasi belajar dibandingkan dengan strategi pembelajaran konvensional.

\section{Saran}

Berdasarkan pembahasan dan kesimpulan dalam penelitian ini. Peneliti memberikan saran sebagai berikut:

1. Dalam mengajar perlu digunakannya strategi yang bervariasi, karena tidak semua materi cocok dengan pembelajaran konvensional.

2. Pemilihan strategi pembelajaran yang bervariasi dan tepat dapat mempengaruhi prestasi serta minat belajar peserta didik terhadap mata pelajaran tersebut.

3. Perlu adanya penelitian lanjutan mengenai penerapan strategi pembelajaran think talk write pada materi yang berbeda.

\section{DAFTAR PUSTAKA}

Trianto. 2010. Model Pembelajaran Terpadu. Jakarta: Bumi Aksara.

Uno, Hamzah B. 2012. Model Pembelajaran Menciptakan Proses Belajar Mengajar yang Kreatif dan Efektif. Jakarta: Bumi Aksara.

Hamdayana, Jumantana. 2014. Model dan Metode Pembelajaran Kreatif dan Berkarakter. Bogor: Ghalia Indonesia.

Shoimin, Aris. 2014. 68 Model Pembelajaran Inovatif Dalam Kurikulum 2013. Yogyakarta: ArRuzz Media. 
Solihatin, Etin, dan Raharjo. 2008. Cooperative Learning Analisis Model Pembelajaran IPS. Jakarta : Bumi Aksara.

Kunandar. 2011. Langkah Mudah Penelitian Tindakan Kelas Sebagai Pengembangan Profesi Guru. Jakarta: Raja Grafindo Persada.

Lie, Anita. 2008. Cooperative Learning. Jakarta: Grasindo.

Isjoni. 2013. Cooperative Learning Efektivitas Pembelajaran Kelompok. Bandung: Alfabeta.

Rima. 2013. Model Pembelajaran Cooperatif Learning. (online) tersedia: hhtp://buanatiwi.wordpress.com/201 3/04/09/model-pembelajarancooperatif-learning/ (20 Januari 2015)

Huda, Miftahul. 2014. Model-Model Pengajaran dan Pembelajaran. Yogyakarta: Pustaka Pelajar.

Suyanto. 2009. Menjelajar Pembelajaran Inovatif. Sidoarjo: Masmedia Buana Pustaka.

Arikunto, Suharsimi. 2013. Prosedur Penelitian Suatu Pengembangan Praktik. Jakarta: PT. Rineka cipta. 